\title{
PENGARUH SUMBERDAYA POLITIS TERHADAP KINERJA PERBANKAN PUBLIK DI INDONESIA
}

\author{
Badri Munir Sukoco \\ Sri Gunawan \\ Ngesthi Nirmala Dewi \\ Departemen Manajemen, Fakultas Ekonomi dan Bisnis, Universitas Airlangga \\ badri@feb.unair.ac.id, sgunawan22@gmail.com,dan dewingesthi@gmail.com
}

\begin{abstract}
Many companies in Indonesia employ former or current officers as board of directors and commissioners, which is known as political resources. However, there is no empirical evidence whether collecting and managing political resources will positively contribute to the companies' performance. To clarify the issue, we analyze data among publicly listed banking in Indonesia from 2008 up to 2010. The results indicate that political resources of board of directors (BOD) negatively influence return on assets (ROA). The influence of board of commissioners' (BOC) political resources has no empirical evidence to support the idea that collecting politicians could increase companies' performance. Managerial and academic implications are further discussed.
\end{abstract}

Keywords: political resources, performance, and banking in Indonesia

\begin{abstract}
Abstrak
Banyak perusahaan di Indonesia menggunakan pejabat atau mantan pejabat sebagai anggota dewan direksi atau dewan komisaris, yang mana dikenal sebagai sumberdaya politis perusahaan. Namun belum ada bukti empiris apakah mengumpulkan dan mengelola sumberdaya politis tersebut akan berkontribusi positif terhadap kinerja perusahaan. Untuk mengklarifikasi hal tersebut, peneliti menganalisa data diantara perbankan Indonesia yang terdaftar pada Bursa Efek Indonesia (BEI) dari tahun 2008 hingga tahun 2010. Hasil analisa mengindikasikan bahwa sumberdaya politis yang ditempatkan sebagai dewan direksi memiliki pengaruh yang negatif terhadap return on assets (ROA). Pengaruh sumberdaya politis yang ditempatkan sebagai dewan komisaris tidak mendapatkan dukungan empiris akan meningkatkan kinerja perusahaan. Implikasi manajerial dan akademis akan dibicarakan lebih lanjut dalam tulisan ini.
\end{abstract}

Kata kunci: sumberdaya politis, kinerja, perbankan di Indonesia

\section{LATAR BELAKANG}

Densitas yang tinggi pada industri perbankan Indonesia dengan pelayanan yang tidak jauh berbeda membuat dinamika persaingan sangat tinggi. Menurut Barney (1991), perusahaan akan memiliki keunggulan bersaing bilamana sumberdaya yang dimilikinya memiliki karakteristik valuable (bernilai), rareness (jarang), inimitable (tidak dapat ditiru), dan not substitutable (tidak tergantikan) yang disingkat dengan VRIN. Konsep resource-based view RBV (Wernerfelt, 1984) berargumentasi bahwa semua sumberdaya perusahaan, baik yang tangible maupun intangible, akan berperan dalam menunjang keunggulan bersaing bila- mana memenuhi kriteria VRIN. Sumberdaya yang tangible sangat mudah ditemukan dan terlihat pada masing-masing bank yang berstatus publik di Indonesia, misalnya jumlah kantor cabang, jumlah karyawan, jumlah aset tetap, dan sumberdaya fisik lainnya. Namun penelitian yang ada selama ini cenderung mengabaikan sumberdaya intangible apakah yang akan berpengaruh terhadap kinerja perbankan.

Industri perbankan di Indonesia merupakan industri yang diatur secara ketat (highly regulated) oleh pemerintah melalui Bank Indonesia sebagai otoritas moneter. Pemerintah juga memiliki alasan untuk mempertahankan 
kontrol tersebut, misalnya kemampuan untuk mengintervensi ketika stabilitas pasar keuangan terancam dan kemampuan untuk menyalurkan pinjaman bank kepada perusahaan dan industri tertentu (Dinc, 2005; Sapienza, 2004). Dalam industri yang highly regulated, Hillman (2005) berpendapat bahwa pelaku industri cenderung mengandalkan sumberdaya politis (political resources) sebagai faktor penunjang kinerja perusahaan. Hal ini dikarenakan sumberdaya politis tersebut akan membantu dalam dealing dengan regulasi-regulasi yang ada (mis: Okhmatovsky, 2010; Sheng, Zhou, dan Li, 2011).

Penelitian terdahulu berargumentasi dan juga melaporkan adanya korelasi positif antara sumberdaya politisdengan kinerja organisasi (mis: Selznick, 1949; Hillman, Zardkoohi, danBierman, 1999). Teori ketergantungan sumber daya (Pfeffer dan Salancik, 2003) danliteratursumber dayapolitik (Hillman, Keim,danSchuler, 2004) menunjukkan bahwa sumberdaya politis memberi legitimasi, status, dan akses berharga kepada sumber daya dan informasi dalam berbagai bentuk. Studi empiris dikonteks negara maju juga cenderung mengkonfirmasikan bahwa hubungan dengan politisi dan badan pengawas menghasilkan efek yang positif padanilai perusahaan (mis: Hillman, 2005; Goldman, Rocholl, dan So, 2009).

Dalam konteks industri perbankan Indonesia, sebagian besar bank yang berstatus publik memiliki dewan direksi maupun dewan komisaris yang terkait dengan latar belakang politis. Dari 31 bank yang berstatus publik, terdapat 10 bank yang menggunakan dewan direksi yang berstatus politis. Proporsi ini justru semakin meningkat pada posisi komisaris, yang mana 28 bank memiliki anggota dewan komisaris yang berlatar belakang politis. Fenomena inilah yang mendasari dilakukannya penelitian ini, apakah sumberdaya politis yang terdapat pada anggota dewan direksi maupun dewan komisaris berkontribusi terhadap kinerja perusahaan?Apakah sumberdaya politis yang dimiliki oleh perusahaan pada dewan direksi atau dewan komisaris memiliki pengaruh yang relatif sama atau cenderung bertentangan?

\section{KAJIAN PUSTAKA}

Perusahaan merupakan kumpulan dari sumberdaya yang produktif (Penrose, 1959), dan setiap perusahaan memiliki sumberdaya yang berbeda satu sama lain sehingga akan memiliki kinerja yang juga berbeda (mis: Amit and Schoemaker, 1993; Wernerfelt, 1984). Hal inilah yang mendasari konsep Resource-Based View (RBV), dimana sumberdaya, kapabilitas, dan kompetensi akan memfasilitasi pencapaian keberlanjutan keunggulan bersaing sebuah perusahaan, dimana strategi yang digunakan mampu memaksimalkan sumberdaya yang dimiliki (mis: Peteraf, 1993; Wernerfelt, 1984).

Peneliti sebelumnya banyak menggunakan istilah sumberdaya sebagai istilah yang umum digunakan untuk input prosesproses yang dilakukan di sebuah perusahaan, namun dalam konteks RBV, sumberdaya strategis (strategic resources) yang menjadi fokus (Amit and Shoemaker, 1993; Barney, 1991). Lebih lanjut, Barney (1991) mengajukan bahwa kepemilikan sumberdaya yang VRINakan menjamin keberlanjutan keunggulan bersaing sebuah perusahaan. Dalam artikel selanjutnya, Barney dan Clark (2007) berargumentasi bahwa kepemilikan sumberdaya yang berkriteria VRIN saja tidak cukup bila tidak dilengkapi dengan kemampuan perusahaan untuk mendapatkan nilai ekonomis dari sumberdaya yang dimiliki.

Barney (1991) mengklasifikasikan sumberdaya menjadi tiga golongan, yakni sumberdaya fisik, sumberdaya manusia, dan sumberdaya organisasi. Sumberdaya fisik meliputi teknologi fisik yang digunakan perusahaan, pabrik dan peralatan, jaringan kantor, aset perusahaan, lokasi, jumlah tenaga kerja yang dimiliki perusahaan, dan akses ke bahan baku (Williamson, 1975). Sumberdaya manusia meliputi pelatihan, pengalaman, pertimbangan, hubungan, dan nasehat yang dimiliki oleh sumberdaya internal perusahaan; sedangkan sumberdaya organisasi terdiri atas perencanaan formal dan informal, struktur koordinasi, dan hubungan yang dimiliki individu maupun perusahaan dengan pihak di luar perusahaan (Barney, 1991).

Sumberdaya politis termasuk golongan ketiga, didefinisikan sebagai kumpulan dari aset-aset dan ketrampilan politis yang unik dan dimiliki sebuah perusahaan untuk berpartisipasi dalam mempengaruhi keputusan pemerintah atau menghadapi persaingan (Boddewyn and Brewer, 1994; Dean dan Brown, 1995). Mengingat sumberdaya politis bukanlah aset yang 
dapat diperdagangkan dan dapat memberikan kontribusi positif kepada perusahaan, banyak akademisi yang menggunakan RBV sebagai teori yang mendasari pembahasannya (mis: Hillman dan Hitt, 1999; Hillman, 2005).

Terdapat dua pendekatan bagaimana perusahaan memanfaatkan sumberdaya politis (Hillman dan Hitt, 1999), yakni pendekatan transaksional dan relasional. Pendekatan yang pertama dilakukan untuk memberikan respon terhadap keputusan pemerintah (mis: Buccholz, 1992; Yoffie, 1987), dimana perusahaan akan menyusun strategi yang tepat setelah keputusan atau kebijakan pemerintah dikeluarkan. Pendekatan yang kedua dilakukan oleh perusahaan dengan membangun hubungan jangka panjang dengan pihak pemerintah, sehingga ketika kebijakan akan dikeluarkan, perusahaan lebih mudah mempengaruhi kebijakan yang akan diambil. Pendekatan pertama berhorizon pendek dan fokus pada transaksi yang dilakukan antara perusahaan dengan agen pemerintah, sedangkan pendekatan relasional berhorizon panjang dan fokus pada struktur dan proses dari hubungan yang dibangun (Macnell, 1974). Dalam banyak hal, pendekatan yang kedua akan membentuk modal sosial (social capital) yang terbentuk dari hubungan timbal balik antara perusahaan dengan agen pemerintah (Nahapiet dan Ghoshal, 1998). Keberlanjutan hubungan akan menimbulkan kepercayaan (trust), sehingga kerjasama akan lebih mudah dilakukan.

Lebih jauh, Hillman dan Hitt (1999) mengajukan 3 strategi dasar yang digunakan perusahaan untuk memiliki sumberdaya politis, yakni informasi, insentif keuangan, dan pembangunan konstituen. Strategi pertama digunakan perusahaan dengan memberikan informasi yang akan menguntungkan perusahaan sebelum kebijakan pemerintah diputuskan. Strategi kedua dengan memberikan insentif keuangan, baik kepada pemerintah maupun pejabatnya, agar kebijakan yang disusun menguntungkan perusahaan. Kedua strategi pertama tersebut langsung mentargetkan kepada pengambil keputusan secara langsung, sedangkan strategi ketiga dilakukan dengan mendapatkan dukungan dari konstituen atau masyarakat untuk mendukung kebijakan yang akan menguntungkan perusahaan. Dalam konteks penelitian ini, strategi kedua yang akan digunakan, mengingat pemberian insentif kepada pejabat atau mantan pejabat dilakukan secara langsung, meskipun diberikan atas layanan yang mereka lakukan sebagai anggota dewan direksi atau dewan komisaris.

Dalam penelitian awal yang terkait dengan ekonomi politik, Pittman (1977) dan Zardkoohi (1985) menemukan bahwa perusahaan yang rentan terpengaruh oleh kebijakan yang dikeluarkan pemerintah akan terlibat dalam banyak aktifitas politik guna mempengaruhinya. Hal yang sama juga dikemukakan oleh Lang dan Lockhart (1990) dan Mahon dan Murray (1981) bahwa perusahaan yang beroperasi pada industri yang banyak diatur oleh pemerintah (highly regulated industry), dalam konteks ini adalah perbankan di Indonesia, ditemukan menggunakan lebih banyak agen pemerintah dalam dewan direksi atau komisaris dibandingkan industri yang tidak terlalu diatur oleh pemerintah.

Sumberdaya politis yang dimiliki perusahaan dengan menempatkan pejabat atau mantan pejabat pemerintah pada dewan direksi atau dewan komisaris umum dilakukan (Hillman dan Hitt, 1999)karena pemerintah memiliki peran penting dalam mengatur bisnis di sebuah negara (Hillman, 2005). Beberapa manfaat yang didapatkan diantaranya: Pertama, membawa informasi yang unik terkait dengan kebijakan yang akan diambil oleh pemerintah dimana prosesnya sangat kompleks dan mahal bila perusahaan mengintervensinya secara langsung (Hillman dkk., 1999; Lester, Hillman, Zardkoohi, dan Cannella, 2008). Kedua, memberikan akses perusahaan untuk berkomunikasi kepada pejabat, politisi dan para pengambil keputusan dimana dewan direksi atau dewan komisaris memiliki hubungan baik (Hillman, 2005). Ketiga, memberikan akses kepada pejabat, politisi dan para pengambil keputusan untuk mempengaruhi kebijakan yang akan diambil (Pfeffer, 1972). Keempat, memberikan legitimasi sosial dan politis kepada perusahaan karena mendapatkan dukungan dari pejabat pemerintah atau politisi (Baum dan Oliver, 1991; Galaskiewicz dan Wasserman, 1989). Kelima, perusahaan mampu mengakses sumberdayasumberdaya penting yang dikuasai pemerintah (Xin dan Pearce, 1996). Keenam, perusahaan mendapatkan perlakuan istimewa terkait dengan proses birokrasi yang terkait dengan penegakan peraturan atau perundang-undangan (Fisman, 2001; Johnson dan Mitton, 2003). 
Kemanfaatan tersebut menjadikan kinerja perusahaan akan meningkat, seperti yang dilaporkan oleh Fisman (2001) bahwa kedekatan hubungan politis (melalui penempatan pejabat atau mantan pejabat sebagai dewan direksi atau dewan komisaris) dengan rezim Soeharto merupakan faktor terpenting kesuksesan sebuah perusahaan karena akses yang lebih luas terhadap sumberdaya-sumberdaya yang dikuasai negara. Hal yang sama juga ditunjukkan oleh Johnson dan Mitton (2003) bahwa perusahaan yang terafiliasi secara politis dengan pemerintahan Malaysia menikmati banyak keuntungan ketika krisis moneter menjangkiti Asia pada tahun 1997-1998. Tidak hanya di negara berkembang, bahkan di Amerika Serikat penggunaan politisi untuk duduk di kursi dewan direksi atau komisaris juga lazim dilakukan. Misalnya, Hillman (2005) mengilustrasikan duduknya Vernon Jordan sebagai dewan komisaris di 12 perusahaan yang terdaftar pada Fortune 500 pada era 1990-an dikarenakan kedekatannya dengan Presiden USA saat itu, Bill Clinton.

Namun apakah penempatan politisi pada dewan direksi memiliki kontribusi yang sama positifnya terhadap kinerja perusahaan dengan menempatkannya pada dewan komisaris? Peneliti beragumen bahwa keberadaan politisi di dewan direksi akan memiliki efek yang berbeda terhadap kinerja perusahaan dibandingkan politisi yang duduk di dewan komisaris. Menjadi anggota dewan direksi meningkatkan peluang politisi untuk mengambil keputusan yang akan menguntungkannya secara politis (Rokkan, Heide, dan Wathne, 2003). Mereka cenderung berperilaku yang oportunis untuk mendapatkan manfaat secara pribadi (umumnya manfaat keuangan) dibandingkan manfaat bagi perusahaan dengan biaya dari perusahaan (Shleifer dan Vishny, 1994). Mereka juga cenderung mengeluarkan keputusan yang menghasilkan keuntungan sosial lebih tinggi walaupun keuntungan bagi perusahaan yang lebih rendah (Dinc, 2005). Hal inilah yang menjadikan kepemilikan sumberdaya politis pada dewan direksi cenderung memberikan efek negatif terhadap kinerja perusahaan. Sehingga didapatkan hipotesis sebagai berikut:

$H_{l}$ : Sumberdaya politis perbankan yang dimiliki oleh dewan direksi berpengaruh negatif terhadap kinerja perusahaan
Sebaliknya, mendudukkan politisi pada dewan komisaris akan memberikan efek yang positif terhadap kinerja perusahaan. Hillman (2005) berpendapat bahwa politisi yang menjadi dewan komisaris akan menjadi sumber legitimasi dan nasehat yangberharga terkait kebijakan-kebijakan pemerintah. Mereka juga akan memberikan peluang bagi perusahaan untuk mempengaruhi kebijakan yang akan dibuat oleh pemerintah dengan memberikan akses kepada perusahaan untuk berdiskusi dengan pengambil keputusan. Mengingat kapasitas komisaris hanya berupa arahan atau nasehat kepada direksi, perilaku oportunis yang mengakibatkan conflict of interest akan dapat diminimalisir; sehingga kemanfaatan akan keberadaan sumberdaya politis melalui dewan komisaris akan lebih dapat dioptimalkan dibandingkan biaya yang ditimbulkannya. Sehingga terdapat hipotesis berikut:

$\mathrm{H}_{2}$ : Sumberdaya politis perbankan yang dimiliki oleh dewan komisaris berpengaruh positif terhadap kinerja perusahaan

\section{METODE PENELITIAN}

Penelitian ini menggunakan data yang dimiliki oleh bank umum di Indonesia yang telah go public dengan harapan informasi yang tersedia relatif lengkap, terutama yang terkait dengan latar belakang anggota dewan direksi dan dewan komisaris. Terkumpul data panel dari 31 bank umum selama 3 tahun, antara tahun 2008 hingga tahun 2010. Penelitian ini dimulai tahun 2008 mengingat pada tahun tersebut dimulai krisis ekonomi dunia yang dipicu oleh subprime mortgage di USA dan diakhiri tahun 2010 dikarenakan ketersediaan data keuangan untuk tahun 2011 belum tersedia ketika penelitian ini berakhir. Data yang dikumpulkan berasal dari laporan keuangan perusahaan setiap tahun, Direktorat Perbankan Indonesia, Bursa Efek Indonesia, dan informasi lain yang relevan dan terkait dengan latar belakang politis dewan direksi dan dewan komisaris.

Menggunakan definisi tangible resources dari Barney (1991), penelitian ini mengoperasionalkan sumberdaya fisik dari jumlah aset, pegawai, dan cabang yang dimiliki oleh masing-masing perusahaan sebagai variabel kontrol. Selain itu, penelitian ini menggunakan jumlah dewan direksi dan dewan komisaris sebagai kontrol, seperti yang digunakan 
oleh Hillman (2005). Adapun variasi umur yang dimiliki oleh dewan direksi untuk mengontrol pengaruh yang diajukan oleh Upper Echelon Theory (Hambrick dan Mason, 1984). Selain itu, peneliti juga mengontrol tahun yang digunakan, dimana tahun 2008 sebagai tahun dasar.

Peneliti mengoperasionalkan sumberdaya politis, baik yang dimiliki oleh dewan direksi dan dewan komisaris, dari komposisi anggotanya yang berlatar belakang politis dibandingkan dengan jumlah keseluruhan anggota dewan. Operasionalisasi ini diinspirasi oleh pendekatan yang dimiliki oleh $\mathrm{Li}$ dan Zhang (2007), Okhmatovskiy (2010), dan Sheng dkk. (2011). Operasionalisasi ini dipilih untuk mengantisipasi keberagaman pelaporan yang dilakukan oleh perbankan terkait dengan tanggal penunjukan atau tanggal efektif bekerja bagi masing-masing dewan direksi atau dewan komisaris. Selain itu, jumlah dewan direksi maupun dewan komisaris selalu berfluktuasi dari waktu ke waktu. Misalnya pada tahun 2008 dan 2009, Bank Mega Tbk memiliki dewan komisaris sebanyak 3 orang, namun tahun 2010 naik menjadi 4 orang. Adapun dewan direksi bertambah dari 5 orang pada tahun 2008 menjadi 7 orang pada tahun 2009 dan 2010. Return on aset (ROA) dioperasionalkan melalui perbandingan antara laba bersih terhadap total aset yang dimiliki oleh sebuah bank, dimana data yang digunakan di-lag (satu tahun setelah tahun anggaran berjalan) untuk melihat dampak perubahan komposisi dewan direksi dan dewan komisaris.

\section{ANALISA}

Struktur perbankan Indonesia berdasarkan undang-undang terdiri atas bank umum dan bank perkreditan rakyat (BPR). Hingga Desember 2011, terdapat 120 bank umum dan 1.837 BPR. Dalam kegiatan usahanya, bank umum dapat melaksanakan usaha berdasarkan prinsip konvensional maupun syariah; sedangkan BPR harus memilih salah satu. Terdapat 9 bank umum dengan modal inti lebih dari Rp. 10 triliun, 44 bank umum dengan modal inti antara Rp. 1 hingga 10 triliun, dan sebagian besar (67 bank umum) memiliki modal Rp. 100 miliar hingga Rp. 1 triliun. Terjadi penurunan aset yang cukup signifikan dari semua bank umum Indonesia pada tahun
2009 (Rp. 5.534,11 triliun) ke tahun 2010 (Rp. $3.008,85$ triliun), namun naik kembali menjadi Rp. 3.652,83 triliun pada tahun 2011. Uniknya, dana pihak ketiga selalu naik sebesar 18,79\% per tahun hingga mencapai Rp. 2.784,91 triliun pada akhir tahun 2011. Kenaikan yang sama juga terjadi pada ROA, dimana rata-rata kenaikannya dalam 3 tahun terakhir sebesar 7,98\% menjadi 3,03\% pada akhir tahun 2012.

Dari 120 bank umum, 4 bank dimiliki oleh pemerintah dan sisanya dimiliki oleh swasta. Dari sejumlah itu, terdapat 31 bank yang telah mencatatkan diri ke Bursa Efek Indonesia (BEI, 2012). Sembilas belas bank mencatatkan diri setelah krisis ekonomi tahun 1998, sedangkan 12 bank telah menjadi perusahaan publik sebelumnya. Saham yang dicatatkan (listed) juga beragam, Seperempat (31 buah) dari jumlah bank umum tersebut telah go public dengan saham yang dijual (listed) juga masih relatif kecil, antara $0.003 \%$ (Bank Mutiara) hingga 49,90\% (BCA) dari keseluruhan saham bank, dengan rata-rata sebesar 22,2\%. Ada 6 bank yang memiliki pegawai lebih dari 10.000 orang, dan sisanya memiliki pegawai antara 1.000 hingga 10.000 orang. Terdapat 3 bank yang memiliki kantor cabang lebih dari 1.000 buah, jumlah yang sama juga terdapat pada bank dengan kantor cabang antara 500 hingga 1.000 buah; sisanya memiliki kantor cabang kurang dari 500 buah. Enam bank dengan aset tetap lebih dari Rp. 100 triliun, 3 bank dengan aset antara Rp. 50 hingga 100 triliun, dan sisanya memiliki aset yang lebih kecil. Adapun laba bank umum terbuka dengan jumlah lebih dari Rp. 1 triliun hanya diperoleh 5 bank, 12 bank mendapatkan laba dengan rentang antara Rp. 100 miliar hingga Rp. 1 trilun, dan sisanya lebih kecil dari Rp. 100 miliar. Berikut ini adalah statistik yang menggambarkan variabel penelitian, baik variabel utama maupun kontrol, beserta nilai rata-rata dan deviasi standar masing-masing variabel (Tabel 1). Tabel tersebut juga menyajikan korelasi antar variabel yang digunakan.

Untuk menguji hipotesa yang diajukan dalam penelitian ini, regresi linear berganda digunakan. Sebelum melakukannya, peneliti melakukan uji asumsi klasik sesuai dengan saran dari Gujarati (2010). Untuk mengetahui multikolinieritas antar variabel, nilai tolerance dan variance inflation factor (VIF) dijadikan 
tolok ukur; yang mana tidak ada nilai tole rance $<0,200$ dan $\mathrm{VIF}<10$. Uji heteroskedastisitas juga menunjukkan bahwa scatterplot dari data yang digunakan menyebar diantara di- antara sumbu Y. Uji normalitas menggunakan Kolomogorov-Smirnov test juga menunjukkan bahwa tingkat signifikansi diatas 0,05 , sehingga data terdistribusi secara normal.

Tabel 1. Analisa Deskriptif dan Matriks Korelasi

\begin{tabular}{|c|c|c|c|c|c|c|c|c|c|c|c|c|c|c|}
\hline & Mean & S.D. & 1 & 2 & 3 & 4 & 5 & 6 & 7 & 8 & 9 & 10 & 11 & 12 \\
\hline Tahun 2009 & 0.33 & 0.47 & 1.00 & & & & & & & & & & & \\
\hline Tahun 2010 & 0.33 & 0.47 & -0.50 & 1.00 & & & & & & & & & & \\
\hline Jumlah karyawan & 0.87 & 0.71 & -0.03 & -0.03 & 1.00 & & & & & & & & & \\
\hline Jumlah aset & 1.02 & 1.11 & -0.06 & -0.06 & 0.62 & 1.00 & & & & & & & & \\
\hline Jumlah cabang & 0.88 & 1.02 & -0.05 & -0.01 & 0.77 & 0.65 & 1.00 & & & & & & & \\
\hline Jumlah dewan komisaris & 4.68 & 1.91 & 0.00 & -0.04 & 0.53 & 0.58 & 0.65 & 1.00 & & & & & & \\
\hline Jumlah dewan direksi & 6.41 & 2.59 & -0.03 & -0.02 & 0.66 & 0.74 & 0.78 & 0.74 & 1.00 & & & & & \\
\hline Rata-rata umur direksi & 1.54 & 0.52 & -0.03 & -0.12 & 0.04 & 0.04 & -0.02 & -0.20 & -0.10 & 1.00 & & & & \\
\hline Rata-rata umur komisaris & 2.08 & 0.47 & -0.02 & -0.02 & 0.06 & $\theta .02$ & 0.02 & 0.05 & -0.03 & 0.19 & 1.00 & & & \\
\hline Sumberdaya politis direksi & 0.06 & 0.11 & 0.01 & 0.08 & 0.47 & 0.29 & 0.52 & 0.33 & 0.36 & 0.00 & -0.16 & 1.00 & & \\
\hline Sumberdaya politis komisaris & 0.41 & 0.30 & 0.07 & -0.06 & 0.36 & 0.11 & 0.31 & 0.01 & 0.12 & 0.11 & 0.08 & 0.15 & 1.00 & \\
\hline ROA & 1.25 & 2.40 & 0.04 & -0.08 & 0.19 & 0.26 & 0.37 & 0.22 & 0.31 & 0.06 & 0.06 & -0.21 & 0.11 & 1.00 \\
\hline
\end{tabular}

Note: Nilai korelasi $>0,118$ signifikan pada $p<0,05$, nilai korelasi $>0,160$ signifikan pada $p<0,01$.

Tabel 2. Pengaruh Sumberdaya Politis terhadap Kinerja Perbankan di Indonesia

\begin{tabular}{|c|c|c|c|c|}
\hline \multirow[t]{2}{*}{ Variabel Penelitian } & \multicolumn{4}{|c|}{ Variabel Dependen - ROA } \\
\hline & M0 & M1 & M2 & M3 \\
\hline \multicolumn{5}{|l|}{ Variabel Kontrol } \\
\hline Tahun 2009 & 0.084 & 0.076 & 0.082 & 0.075 \\
\hline Tahun 2010 & 0.050 & 0.018 & 0.050 & 0.018 \\
\hline Jumlah karyawan & $-0.302^{+}$ & -0.242 & $-0.310^{+}$ & -0.246 \\
\hline Jumlah asset & 0.049 & 0.028 & 0.052 & 0.029 \\
\hline Jumlah cabang & $0.501^{*}$ & $0.616^{* *}$ & $0.491^{*}$ & $0.612^{* *}$ \\
\hline Jumlah dewan komisaris & -0.047 & -0.033 & -0.041 & 0.031 \\
\hline Jumlah dewan direksi & 0.130 & 0.094 & 0.134 & 0.096 \\
\hline Rata-rata umur direksi & 0.076 & 0.088 & 0.074 & 0.088 \\
\hline Rata-rata umur komisaris & 0.055 & 0.007 & 0.054 & 0.007 \\
\hline \multicolumn{5}{|l|}{ Efek Utama } \\
\hline Sumberdaya politis dewan direksi & & $-0.243^{*}$ & & $-0.242^{*}$ \\
\hline Sumberdaya politis dewan komisaris & & & 0.026 & 0.011 \\
\hline $\mathrm{R}^{2}$ & 0.183 & 0.222 & 0.183 & 0.222 \\
\hline$\Delta \mathrm{R}^{2}$ & & 0.039 & 0.001 & 0.039 \\
\hline$\Delta \mathrm{F}$ & 2.040 & 4.018 & 0.051 & 1.990 \\
\hline Sig & 0.045 & 0.048 & 0.821 & 0.143 \\
\hline
\end{tabular}

Catatan: ${ }^{+}$signifikan pada $\mathrm{p}<0,10,{ }^{*}$ signifikan pada $\mathrm{p}<0,05,{ }^{* *}$ signifikan pada $\mathrm{p}<0,01,{ }^{* * *}$ signifikan pada $\mathrm{p}<0,001$ 
Tabel 2. menyajikan hasil regresi. Penelitian ini menggunakan 8 variabel kontrol, yakni tahun, jumlah karyawan, jumlah aset, jumlah cabang, jumlah dewan direksi, jumlah dewan komisaris, rata-rata umur direksi, dan rata-rata umur komisaris. Kedelapan variabel kontrol tersebut menghasilkan $\mathrm{R}^{2}$ sebesar 0,183 (M0), dimana jumlah karyawan berpengaruh secara negatif $(\beta=-0,302, \mathrm{p}<0,089)$ dan jumlah cabang berpengaruh secara positif dan signifikan $(\beta=0,501, \mathrm{p}<0,05)$ terhadap ROA perusahaan. Adapunkeenam variabel yang lain tidak memiliki pengaruh yang signifikan. Hipotesa pertama memprediksi bahwa sumberdaya politis yang ditempatkan pada dewan direksi akan berpengaruh secara negatif terhadap kinerja perusahaan. Hasil analisa menunjukkan bahwa ketika sumberdaya politis yang dimiliki perusahaan melalui dewan direksi dimasukkan dalam model regresi (M1), terdapat $\Delta R^{2}$ sebesar $0,039(\mathrm{p}<0,048)$. Pengaruh sumberdaya politis sesuai dengan ekspektasi, yakni negatif dan signifikan $(\beta=-0,243$, $\mathrm{p}<0,05$ ); sehingga $\mathrm{H}_{1}$ diterima. Hipotesa kedua menyatakan bahwa terdapat pengaruh positif oleh sumberdaya politis yang ditempatkan pada dewan komisaris terhadap kinerja perusahaan. Hasil analisa menunjukkan bahwa pengaruh positif memang ada $(\beta=0,026, \mathrm{p}<0,821 ; \mathrm{M} 2)$, namun tidak signifikan; sehingga $\mathrm{H}_{2}$ tidak dapat diterima. Hasil analisa tersebut juga konsisten, dimana ketika sumberdaya politis yang dimiliki oleh dewan direksi dan dewan komisaris digabungkan dalam regresi (M3), pengaruh negatif sumberdaya politis dewan direksi terhadap kinerja perusahaan tetap ada dan signifikan.

\section{PEMBAHASAN}

Penelitian ini bermaksud untuk mengetahui kontribusi sumberdaya politis yang dimiliki perbankan publik di Indonesia terhadap kinerjanya. Dari analisa yang dilakukan, terdapat beberapa kesimpulan: Pertama, dari ketiga sumberdaya fisik yang digunakan sebagai variabel dalam penelitian ini, hanya jumlah cabang yang berpengaruh secara positif terhadap ROA yang dimiliki perbankan. Hal ini membuktikan hasil meta-analisis yang dilakukan oleh Crook dkk. (2008) bahwa tangible resources berpengaruh terhadap kinerja perusahaan hanya sebagian dapat dibuktikan.
Industri yang berbeda tentunya membutuhkan tangible resources yang berbeda dalam meningkatkan kinerja perusahaan.

Kedua, latar belakang politis yang dimiliki oleh dewan direksi berpengaruh secara negatif terhadap ROA, adapun efek dewan komisaris positif namun tidak signifikan. Hal ini tentunya sejalan dengan pendapat Okhmatovskiy (2010) bahwa hubungan secara tidak langsung dengan pemerintah, dalam hal ini politisi yang memiliki jabatan publik dan menjadi komisaris, dipercaya oleh investor akan mampu meningkatkan kinerja. Penempatan pejabat atau mantan pejabat dalam dewan komisaris menjadi sumber legitimasi bahwa perusahaan tersebut akan mendapatkan nasihat berharga terkait kebijakan yang sedang diterapkan atau mempengaruhi yang akan dikeluarkan, bahkan dapat memfasilitasinya untuk mendapatkan akses ke sumber daya yang dimiliki oleh pemerintah. Bila hubungan tersebut bersifat langsung, dalam konteks penelitian ini menjadi dewan direksi, cenderung memiliki pengaruh yang negatif sesuai dengan pendapat dari Okhmatovskiy (2010). Hasil ini juga selaras dengan penelitian sebelumnya bahwa menempatkan politisi yang memiliki otoritas langsung terhadap operasional perusahaan (dewan direksi) akan meningkatkan peluang untuk berperilaku oportunis dengan imbal balik yang minim bagi perusahaan (mis: Dinc, 2005; Rokkan dkk., 2003).

Bagi pengelola perbankan nasional, hasil penelitian ini memberikan implikasi sebagai berikut: Pertama, tidak semua tangible resources berpengaruh secara positif terhadap kinerja perbankan, dan pemetaan sumberdaya mana yang memiliki kontribusi riil merupakan langkah awal untuk mengoptimalkannya. Hal ini juga sesuai hasil meta-analysis yang dilakukan oleh Crook dkk. (2008) bahwa identifikasi, pengembangan, dan distribusi nilai dari sumberdaya penting yang dimiliki oleh perusahaan akan menjamin peningkatan kinerja perusahaan. Kedua, menunjuk dewan direksi yang memiliki latar belakang politis cenderung berefek negatif terhadap kinerja perusahaan. Hal ini mungkin disebabkan banyaknya conflict of interest antara pengelolaan bank dengan hasrat politik dewan direksi, sehingga penunjukan mereka lebih baik dihindari. Apalagi Ganesan (1994) menyatakan bahwa pejabat dan mantan pejabat kurang memiliki 
insentif untuk membangun hubungan jangka panjang dengan perusahaan, dan cenderung lebih oportunis (mis: Rokkan dkk., 2003; Shleifer dan Vishny, 1994). Ketiga, meminta pejabat atau mantan pejabat dalam dewan komisaris memberikan sinyal legitimasi kepada investor bahwa perbankan tersebut akan diberikan nasihat yang valid dan krusial (Peng, Tan, dan Tong, 2004), terutama yang terkait dengan kebijakan maupun kewenangan yang dimiliki oleh pemerintah (Hillman dkk., 1999). Namun yang lebih penting adalah komisaris tidak memiliki otoitas secara langsung dalam operasional perusahaan, sehingga perilaku oportunis dapat dihindarkan.

Selain implikasi manajerial, beberapa implikasi akademis dari penelitian ini adalah: Pertama, penelitian ini memberikan gambaran secara utuh bahwa tangible dan intangible resources memiliki arti penting bagi kinerja perusahaan sebagaimana yang diajukan oleh Barney (1991), Rumelt (1984), dan Wernerfelt (1984) dalam resource-based theory. Kedua, penelitian ini memperluas hasil yang didapatkan oleh Li dan Zhang (2007) dan Sheng dkk. (2011) bahwa kedekatan hubungan dengan pemerintah dan politisi (sumberdaya politis) dapat dijadikan sumberdaya alternatif bagi perusahaan untuk menunjang kinerjanya. Ketiga, penelitian ini memperluas hasil penelitian Hillman (2005) dan Okhmatovskiy (2010) bahwa keberadaan sumberdaya politis yang ditempatkan sebagai dewan direksi dan dewan komisaris memiliki efek yang berbeda terhadap kinerja perusahaan, dan selama ini belum pernah dibuktikan secara empiris.

Meskipun penelitian ini didesain dengan baik untuk menjawab pertanyaan penelitian yang diajukan, terdapat beberapa kelemahan yang dapat digunakan sebagai acuan bagi penelitian ke depan. Pertama, hanya seperempat dari bank umum yang beroperasi di Indonesia go public dengan harapan semua data lebih tersedia dibandingkan perbankan yang tidak go public. Penggunaan keseluruhan populasi akan meningkatkan validitas dari hasil penelitian ini sebagai bahan pengambilan keputusan bagi pengelola atau pemilik bank di Indonesia. Kedua, penelitian ini hanya menggunakan industri perbankan sebagai konteks industri yang highly regulated, dan penggunaan politisi sebagai dewan direksi maupun komisaris juga banyak ditemui pada industry lain- nya. Penelitian selanjutnya dapat memperbandingkan apakah perbedaan konteks antara high vs. low regulated industries memang ada, sesuai dengan prediksi dari Hillman dan Hitt (1999) dan Hillman (2005). Ketiga, penelitian ini hanya menggunakan data sekunder dari perbankan yang tercatat di Bursa Efek Indonesia dengan rentang waktu tertentu. Keterbatasan informasi dan rigid-nya operasionalisasi dari variabel-variabel penelitian menjadikan penelitian cross-sectional melalui survey menjadi metode alternatif, sebagaimana yang digunakan oleh Li dan Zhang (2007) dan Sheng dkk. (2011).

\section{DAFTAR PUSTAKA}

Amit, R., and Schoemaker, P.J. 1993. Strategic Assets and Organisational Rent. Strategic Management Journal. 14. 33-46.

Barney, J. 1991. Firm Resources and Sustained Competitive Advantage,Journal of Management. 17. 99-120.

Barney, J.B. and Clark, D.N. 2007. Resourcebased Theory: Creating and Sustaining Competitive Advantage. New York: Oxford University Press.

Baum, J.A.C., and Oliver, C. 1991. Institutional Linkages and Organizational Mortality. Administrative Science Quarterly. 36. 187-218.

Boddewyn, J., and Brewer, T. 1994. International Business Political Behavior: New Theoretical Directions. Academy of Management Review. 19. 119-143.

Buchholz, R. 1992. Business Environments and Public Policy. Englewood Cliffs, NJ: Prentice-Hall.

Crook, T.R., Ketchen Jr, D.J., Combs, J.G., and Todd, S.Y. 2008. Strategic Resources and Performance: A Meta-Analysis. Strategic Management Journal. 29. 1141-1154.

Dean, T.J., and Brown, R.L. 1995. Pollution Regulation as a Barrier to New Firm Entry: Initial Evidence and Implications for Future Research. Academy of Management Journal. 38. 288-303. 
Dinc, I.S. 2005. Politicians and Banks: Political Influences on Government-Owned Banks in Emerging Markets. Journal of Financial Economics. 77. 453-79.

Direktorat Perbankan Indonesia 2009

Direktorat Perbankan Indonesia 2010

Edrzej, G.F., Mellahi, K., and Pigman, G.A. 2006. First Mover Advantages In International Business and Firm-Specific Political Resources. Strategic Management Journal. 27. 321-345.

Fisman, R. 2001. Estimating the Value of Political Connections. American Economic Review 91. 1095-102.

Galaskiewicz, J., and Wasserman, S. 1989. Mimetic Processes within an Interorganizational Field: An Empirical Test. Administrative Science Quarterly. 34. 454-479.

Ganesan, S. 1994. Determinants of Long-Term Orientation in Buyer-Seller Relationships. Journal of Marketing. 58. 1-19.

Goldman, E., Rocholl, J., and So, J. 2009. Do Politically Connected Boards Affect Firm Value. Review of Financial Studies. 22. 2331-2360.

Gujarati, D.N. 2006. Essentials of Econometrics. $3^{\text {rd }}$ Edition, McGraw-Hill: Boston

Hambrick, D.C., and Mason, P.A. 1984. Upper Echelons: The Organization as A Reflection of Its Top Managers. Academy of Management Review. 9. 193-206.

Hillman, A., and Hitt, M. 1999. Corporate Political Strategy Formulation: A Model of Approach, Participation and Strategy Decisions. Academy of Management Review. 20. 193-214.

Hillman, A., Keim, G., dan Schuler, D. 2004.C orporate Political Strategies: A Review and Research Agenda. Journal of Management. 30. 837-857.

Hillman, A., Zardkoohi, A., and Bierman, L. 1999. Corporate Political Strategies and Firm Performance: Indications of Firm-specific Benefits from Personal
Service in the U.S. Government. Strategic Management Journal. 20. 67-81.

Hillman, A.J. 2005. Politicians on the Board of Directors: Do Connections Affect the Bottom Line? Journal of Management. 31. 464-81.

Johnson, S., and Mitton, T. 2003. Cronyism and Capital Controls: Evidence from Malaysia. Journal of Financial Economics. 67. 351-82.

Lang, J.R., and Lockhart, D.E. 1990. Increased Environmental Uncertainty and Changes in Board Linkage Patterns. Academy of Management Journal. 33. 106-28

Lester, R.H., Hillman, A., Zardkoohi, A., and Cannella, A.A. 2008. Former Government Officials as Outside Directors: The Role of Human and Social Capital. Academy of Management Journal. 51. 999-1013.

Li, J.J., and Zhang, Y. 2007. The Role of Managers' Political Networking and Functional Experience in New Venture Performance: Evidence from China's Transition Economy. Strategic Management Journal. 28. 791-804.

Macneil, I. 1974. The Many Futures of Contract. Southern California Law Review. 47. 688-816.

Mahon, J., and Murray, E. 1981. Strategic Planning for Regulated Companies. Strategic Management Journal. 2. 251262.

Nahapiet, J., and Ghoshal, S. 1998. Social Capital, Intellectual Capital, and the Organizational Advantage, Academy of Management Review. 23. 242-266.

Okhmatovskiy, I. 2009. Performance Implications of Ties to the Government and SOEs: A Political Embeddedness Perspective. Journal of Management Studies. 47. 1020-1047.

Peng, M.W., Tan, J., and Tong, T.W. 2004. Ownership Types and Strategic Groups in an Emerging Economy. Journal of Management Studies. 41. 1105-1129. 
Penrose, E. 1959. The Theory of the Growth of the Firm, New York: Wiley.

Peteraf, M.A. 1993. The Cornerstones of Competitive Advantage: A Resource-based View. Strategic Management Journal. 14. 179-191.

Pfeffer, J. 1972. Size and Composition of Corporate Boards of Directors: The Organization and its Environment. Administrative Science Quarterly. 17. 218-228.

Pittman, R. 1976. The Effects of Industry Concern in Three 1971 U.S. Senate Campaigns. Public Choice. 23. 71-80.

Rokkan, A.I., Heide, J.B., and Wathne, K.H. 2003. Specific Investments in Marketing Relationships: Expropriation and Bonding Effects. Journal of Marketing Research. 40. 210-24.

Sapienza, P. 2004. The Effects of Government Ownership on Bank Lending. Journal of Financial Economics. 72. 357-84.

Selznick, P. 1949. TVA and the Grassroots, New York: Harper and Row.

Sheng,S-B., Zhou, K.Z., and Li, J.J. 2011. The Effects of Business and PoliticalTies on Firm Performance: Evidence from China. Journal of Marketing. 75. 1-15.

Shleifer, A., and Vishny, R.W. 1994. Politicians and Firms. Quarterly Journal of Economics. 109. 995-1025.

Wernerfelt, B. 1984. A Resource-based View of the Firm. Strategic Management Journal. 5. 171-180.

Williamson, 0. 1979. Transaction Cost Economics: The Governance of Contractual Relations. Journal of Law and Economics. 26. 233-261.

Xin, C.R., and Pearce, J.L. 1996. Guanxi: Connections as Substitutes for Formal Institutional Support. Academy of Management Journal. 39. 1641-1658.

Yoffie, D. 1987. Corporate Strategy for Political Action: A Rational Model. In A. Marcus, A. Kaufman, \& D. Beam (Eds.), Business Strategy and Public Policy. 92-111. New York: Quorum.

Zardkoohi, A. 1985. On the Political Participation of the Firm in the Electoral Process. Southern Economic Journal. 51. 804-817. 